\title{
Study of the antibiotic prescription practice for safety purposes for inpatients hospitalized due to pneumonia
}

\author{
Natalia Radeva-Dafinova1, Momchil Velikov¹, Ilko Getov1
}

\begin{abstract}
Improving the safety of the patient is a significant challenge for the national health systems, as it is for many health services around the world. Community-acquired pneumonia (CAP) is a common, potentially life-threatening disease that is associated with much morbidity, mortality and use of healthcare resources. The aim of the study was to clarify and evaluate the frequency of antibiotics' prescribing for inpatients, hospitalized due to CAP, leading factors for prescriptions' changes during treatment and medical doctors' attitude to patient safety problem. We conducted a retrospective investigation of the medical records for 107 inpatients hospitalized due to CAP. The used methods were pseudo-randomization; experts' analysis and non-interventional pharmacoepidemiologycal evaluation of the variations frequencies. We also classify the factors for changes in medicines prescriptions in five main groups. Data shows that more than $33 \%$ of the patients with CAP have had one or more variations in drug therapy during hospital stay. Most common change in the therapy is adding another antibiotic $(67 \%)$ due to lack of therapeutic effect $(63 \%)$ or specifying diagnosis $(26 \%)$. The leading factor for additional antibiotic prescribing is starting therapy without microbiological specification of the diagnosis. Regarding patient safety the interviewed medical doctors (MDs) declared problems about healthcare system financing, institutional limitations, diagnostics, lack of clear rules and standards for practice. Efforts to improve the use of antibiotics for inpatients with CAP should consider the range of barriers that care providers face in everyday practice.
\end{abstract}

KEY WORDS: Patient safety, community-acquired pneumonia, antibiotics, medical doctors' attitude

\section{INTRODUCTION}

Patient Safety is an umbrella term which resides many categories of potential harms to patients: errors, medication problems, post-surgery wound infections, falls, bedsores, technical failures, communication issues, restrictive barriers, etc. The problem is suddenly high on the public agenda, but it is a big and, until recently, hidden and bad studied issue in Bulgaria (1).

Healthcare is not as safe as it should be. Improving the safety of the patient is a significant challenge for the national health system, as it is for many health services around the world (2). In many countries, it has become the main strategy for making improvements in healthcare systems (1). As a prerequisite for developing Patient Safety strategies, governments should take a proac- tive, preventive and systematic attitude. A system-based approach presupposes the systematic design of safe structures, procedures and processes, as well as correct reactions in response to safety incidents (3).

Increasingly, healthcare organizations are becoming aware of the importance of transforming organizational culture in order to improve patient safety. Growing interest in safety culture has been accompanied by the need for assessment tools focused on the medical, economical and cultural aspects of patient safety improvement efforts (4).

The safety of patients in hospital is a small part of a developing scenario in increased perception and reduced acceptance of risk. Treatment in hospitals is more complex than it used to be. More
AFFILIATIONS

${ }^{1}$ Medical University,

Pharmaceutical Faculty,

Sofia, Bulgaria

CORRESPONDENCE

Natalia Radeva-Dafinova

E-mail:

drnradeva@gmail.com

Received:

November 01, 2009

Accepted:

January 13, 2010 
competition in medical care between providers, hospitals, and third party payers, cost-containing and pressure on effectiveness have resulted in reduced staff, shorter hospital stays and more intensive treatment. Different health professionals are involved in patient medication use through dispensing, prescribing and administering medicines. An open dialogue and communication between health professionals is a positive means towards improving patient safety in medication use. This allows both patient and health professionals to monitor the medical condition and to take appropriate actions, if patient safety problem occurs (5).

Community-acquired pneumonia (CAP) is a common, potentially life-threatening disease that is associated with much morbidity, mortality and use of healthcare resources. A better understanding of factors influencing optimal treatment is needed to plan effective change in order to improve prescribing practices and patient safety (6). Appropriate antibiotic therapy remains the cornerstone of management and directly affects the patient safety (7).

The aim of the study was to clarify and evaluate the frequency of antibiotics' prescribing for inpatients, hospitalized due to pneumonia and leading factors for prescriptions' variations during treatment. We also examined the medical doctors' attitude to the problem "patient safety" and to emphasize its importance. During the survey were estimated the main barriers for improving the safety and the needed precautions for creating a more safety healthcare environment.

\section{METHODS}

We conducted a retrospective investigation of the medical records for 107 inpatients hospitalized due to community-acquired pneumonia in a specialized clinic of pneumology and phthisiology at an University hospital in Bulgaria. The used methods for sample selection were pseudo-randomization. The collected data was analyzed applying strict criteria for the type of treatment, variations, outcomes, etc. The survey also includes non-interventional pharmacoepidemiologycal evaluation of the frequency and classification of the factors for changes in antibiotics' prescriptions. The sources for data collection were medical records for patients that have been hospitalized with CAP and for this target group we used a preliminary created schedule model. In the data collecting form there were columns for demographic indexes - sex and age, main diagnosis classified according to the ICD code, duration of hospital stay (in days), initial drug treatment, variations in therapy (day, type of change, reason) and additional comments on medical history (side effects, lack of effect, complications and interactions, etc.). The investigation has been made from the existed electronic data-base at the university multiprofile hospital between medical records collected for patients hospitalized with CAP in the period of October 2008 - March 2009. Finally data for 107 patients has been worked. The total number of patients that had been hospitalized for that period was 1006 (10.6\%), and the inpatients with diagnosis CAP for the same period were $572(18.7 \%)$.

We also used standardized questionnaire for indirect interviewing medical doctors in such multi-profile university hospital. In order to study barriers for appropriate antibiotics use and assess the attitude to patient safety problem the questions were totally 15 divided in three sections - personal data; common practice; knowledge and attitude on the studied problem. 120 inquiry cards were given, 93 were returned and filled in (response rate $-77 \%$ ). After validation process we analyzed 92. The total number of the medical doctors in the studied hospital is 427 and our sample size was $22 \%$.

\section{RESULTS AND DISCUSSION}

\section{Inquired MDs Data Analysis}

After validation the MDs inquiry cards were worked and analyzed. Table 1 presents responders' distribution among age groups.

TABLE 1. Age distribution of the interviewed MDs

\begin{tabular}{lcc}
\hline Age group (years from-to) & Number $(\mathrm{n})$ & Distribution $(\%)$ \\
\hline $25-30$ & 14 & 15 \\
$31-40$ & 24 & 26 \\
$41-50$ & 28 & 30 \\
$51-60$ & 21 & 23 \\
$60+$ & 5 & 6 \\
\hline Total & 92 & 100
\end{tabular}

Among the doctors that have been inquired gender distribution was equally between men (51\%) and women (49\%). The average working experience is 26.7 years. $67 \%$ of the MDs in our sample acquired post-graduate clinical specialization.

Table 2 presents data for most significant problems influencing patient safety according to MDs responses.

TABLE 2. MDs opinions for the most significant problems that influence patient safety

\begin{tabular}{lc}
\hline Responses & $\begin{array}{c}\text { Responses } \\
\text { distribution (\%) }\end{array}$ \\
\hline $\begin{array}{l}\text { Healthcare system financing } \\
\text { Restrictions enforced by the national healthcare insurance }\end{array}$ & 84 \\
provider and other institutions & 58 \\
$\begin{array}{l}\text { The lack of integrated patient safety incident reporting } \\
\text { system }\end{array}$ & 32 \\
Patients are not enough informed & 13 \\
Lack of normative basis & 9 \\
Medical errors & 7
\end{tabular}

The total sum of percentages is over $100 \%$ because the responders have been chosen more than one answer.

The important conclusion that we can make from the analyzed data is that the medical doctors lay down as a major problem for providing patient safety the economic and financial elements of the healthcare system. In this way appear the direct ratio between availability of financial resources and the level of patient safety.

It is clear that providing of the safety of patients during their treatment and staying in the hospital is influenced but not completely dependent on the financial security of healthcare. The other restrictions / professional and administrative/ enforced on medical specialists by the National Health Insurance Fund and similar institutions are the problem laid down in the fore. This problem has been mentioned in many publications and in our opinion is the most important one in providing patient safety. The physicians restricted possibilities for professional activity due to financial restrictions, absence of independence in taking 
their decisions and normative limitations reflecting directly in practical plan. The great impression in the answers is neglecting medical errors and faults which followed to worse safety environment. Only 7\% from the doctors admit the existing of a problem which is priority for World Health Organization and other non-governmental health and patients organizations. Around $33 \%$ pointed that consider as significant problem the absence of integral information system. These facts restrict the investigation and analysis of the problem in our country concerning patient safety, medical faults and drug related problems.

On the other hand a national integrated information system is a basic infrastructural prerequisite for developing, applying, valuation, and defining the targets of health reform. It will be a guarantee for improving the results in healthcare in limiting possibilities to increase the budget of the health system.

The next question concerning most often errors and oversights presented in common practice. 48 from the inquired (52\%) answer that they encounter problems in diagnostics and that appear the most frequently made faults. On the second place were selected problems and faults of drug selection, prescribing and applying of drugs - 39\%, then problems concerning contraindications, interactions and side effects $-23 \%$. The lack of effect was indicated as frequently encountered problem in the practice for $11 \%$ (Figure 1 ).

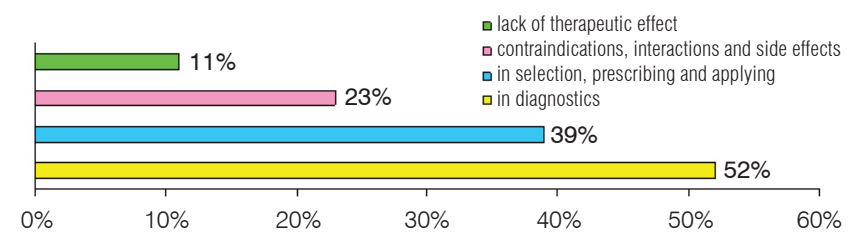

FIGURE 1. Main errors and oversights.

The conclusion which can be made after analyzing the data is that the main errors and oversights in the practice concern diagnosing and all the efforts should be focused of improving the provided care and patient safety. Regarding leading barriers for improving Patient Safety lack of rules and standards for practice - $53 \%$, restrictions of taking individual decisions - 34\%, medical staff communication problems - 33\% and insufficient educational programs $-15 \%$ were declared. The unfinished healthcare system reform influenced the answers. The doctors mentioned the main difficulties for providing adequate level of safety followed from this process. According to medical doctors informational (55\%), economical (48\%), educational (34\%) and legislative $(34 \%)$ measures are required in order to improve safety practices and medical specialists' performance which are in concordance with the leading factors (Figure 2).

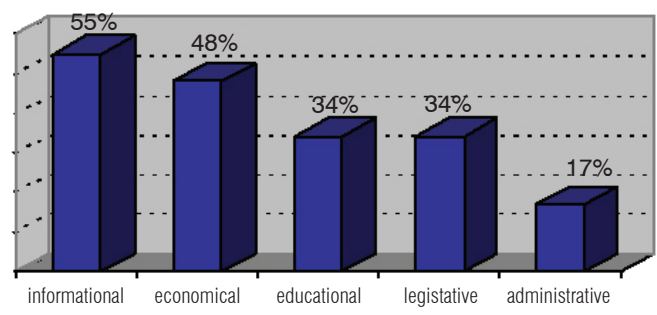

FIGURE 2. Required practical measures for improving patient safety

Regarding the timelines of antibiotic administration, barriers such as conflicting guidelines and organizational factors (de- layed laboratory results, antibiotics not directly available, time spent for administrative issues and restriction of taking selfdecisions) were reported.

\section{Patients' and Drug Therapy Data Analysis}

The collected data from medical records were worked and analyzed. According to the gender prevail females (60\%) and predominant age segment was 51-65 years for patients with CAP and hospital stay of 8.5 days on average.

The primary goals of pharmacotherapy for those patients include eradicating the causative pathogens, resolving the clinical signs and symptoms, minimizing hospitalization, and preventing re-infection. Physicians should choose a medication based on the pharmacokinetic profile, adverse reactions, drug interactions, and cost-effectiveness. Further, patient evaluation should focus on severity of illness, patient age, co-morbidities, clinical presentation, epidemiologic setting, and previous exposure. The majority of patients with CAP are treated empirically based on the most common pathogen(s) associated with the condition.

Mono-therapy was prescribed initially for 74 patients (69\%) and medicines in combination for 33 patients. Medical records' analysis showed that most frequently prescribed antibiotic for initial therapy was Ceftriaxone i.v. for 48 patients - $(44 \%$ of the cases). Combination of Ceftriaxone i.v. + Azithromycin i.v. was prescribed for 26 patients (24\%) and Azithromycin i.v. for 18 patients. As starting therapy the combination of Ceftriaxon i.v. + Azithromycin p.o. was chosen for $5 \%$ of the cases only. There are other therapeutic approaches $(6 \%)$, but they are strictly individual and consistent with any particular case and patient's characteristics (Table 3).

TABLE 3: Antibiotic therapy of CAP

\begin{tabular}{lcccc}
\hline Therapy & \multicolumn{2}{c}{ Initial therapy } & \multicolumn{2}{c}{ Additional therapy } \\
\cline { 2 - 5 } & Patients & Share (\%) & Patients & Share (\%) \\
\hline Ceftriaxone i.v. & 48 & $44 \%$ & - & - \\
Ceftriaxone i.v. + & 26 & $24 \%$ & - & - \\
Azithromycin i.v. & & & & \\
Azithromycin i.v. & 18 & $17 \%$ & 2 & $6 \%$ \\
Ceftriaxone i.v. + & 5 & $5 \%$ & - & - \\
Azithromycin p.o. & & & & \\
Ciprofloxacin i.v. & - & - & 15 & $44 \%$ \\
Metronidazol p.o. & - & - & 9 & $26 \%$ \\
Clarithromycin p.o. & - & - & 5 & $15 \%$ \\
Other & 10 & $6 \%$ & 3 & $9 \%$
\end{tabular}

The additional medicine usually included in the therapy of CAP after determination of the causative pathogen(s). Most frequently added drug was Ciprofloxacin i.v. for 15 patients (44\%). Metronidazol p.o. was selected for 9 patients $(26 \%)$, Clarithromycin for 5 patients (15\%) and Azithromycin i.v. for $6 \%$ of the cases. The change in the therapy reversed the ratio mono / combination therapy ( $48 \%$ for monotherapy to $52 \%$ for combination therapy).

An important aspect of ensuring optimal antibiotic therapy for patients with CAP is the "switch" strategy. Many authors $(8,9)$ suggest that this strategy can reduce costs due to drug administration and length of hospital stay. Targeting patients for early switch from intravenous to oral antibiotic therapy and early hospital discharge is an important strategy in the man- 


\section{Pnömoni nedeniyle hastanede yatan hastalarda antibiyotik reçeteleme uygulamasının belirlen- mesine yönelik güvenlik amaçlı çalışma}

ÖZET: Hasta güvenliğinin geliştirilmesi, tüm dünyada pek çok sağlık servisi için olduğu gibi ulusal sağlık sistemleri için de önemli bir aşamadır. Toplumdan edinilmiş pnömoni (TEP), mortalite, morbidite ve sağlık-bakım harcamalarına neden olan, sık gözlenen ve potansiyel olarak yaşam-tehdit edici olabilen bir hastalıktır. Bu çalışmanın amacı, TEP nedeniyle hastaneye yatırılmış olan hastalarda antibiyotik reçeteleme sıklığının, tedavi sırasında reçetenin değiştirilmesine neden olan önde gelen faktörlerin ve hekimlerin hasta güvenlik sorunlarına yaklaşımlarının belirlenmesi ve değerlendirilmesidir. Çalışma kapsamında TEP nedeniyle hastanede yatan 107 hastanın ilaç kayıtları retrospektif şekilde incelenmiştir. Çalışmada psödo-randomizasyon, uzman analizi ve girişimsel-olmayan farmakoepidemiyolojik değerlendirme yöntemleri kullanılmıştır. Ayrıca ilaç reçetelemesinde değişikliklere neden olan faktörler beş ana grupta sınıflandırılmıştır. Veriler TEP'li hastaların \%33'ten fazlasında hastanede kalış süresince ilaç tedavilerinde bir veya daha fazla değişim varlığını göstermiştir. Tedavide en sık yapılan değişiklik, terapötik etkinin yetersizliği (\%63) veya tanının kesinleştirilmesi (\%26) nedeniyle tedaviye diğer bir antibiyotiğin eklenmesi (\%67) idi. Ek antibiyotik reçetelemesi için önde gelen faktör tanının mikrobiyolojik spesifikasyonu yapılmaksızın tedaviye başlanmış olmasıydı. Hasta güvenliği ile ilgili olarak görüşülen hekimler, sağlık-bakım sistemi finansmanı, kuruma ait sınırıılıklar, tanısal gereçler ve belli uygulama kural ve standartlarının bulunmaması ile ilgili sorunları bildirmişlerdir. TEP tanısıyla hastaneye yatırılan hastalarda antibiyotik kullanımını iyileştirme çabaları sağlık-bakım sağlayıcılarının uygulamada hergün karşılaştıkları engellerin tümünü kapsamalıdır.

ANAHTAR KELIMELER: Hasta güvenliği, toplumdan edinilmiş pnömoni, antibiyotik, hasta-güvenliği, hekim tutumu

agement of community-acquired pneumonia. Unfortunately physicians at the studied clinic stick to intravenous antibiotic therapy. 10 cases (22\%) when i.v. macrolide has been initially prescribed (46 cases), it has been switched to oral one. When the intravenous cephalosporins have been prescribed, in no one of the cases switch has been performed. This approach has been realized most frequently on the 6-th day of the therapy. Notwithstanding many studies $(8,9)$ prove that the early switch ensure better therapeutic outcome for the patient.

The results of our survey also showed that 60 (56\%) of patients were treated with antibiotics before hospitalization and 72 $(67 \%)$ were discharged with ambulatory treatment. Most frequently prescribed drug for home treatment was Ciprofloxacin p.o. for 38 patients $(51 \%)$. Clarithromycin p.o. was prescribed for 24 patients (32\%), Moxifloxacin p.o. for 4 patients and Amoxicillin+Clavulanic acid p.o. for $4 \%$ of the patients.

Data analysis proves our hypothesis for increased share of therapy variations for inpatients with CAP. For 38 hospitalized patients (35\%) have been performed change in drug therapy during hospital stay. Most common change in the therapy is adding one another antibiotic (67\%). In $17 \%$ of the cases had been changed the route of administration, in $7 \%$ had been exchanged drug from the same chemical or therapeutic subgroup and in $7 \%$ drug administration had been stopped. In $2 \%$ of the cases physicians had performed fine tuning of the dosage regimen (Figure 3).

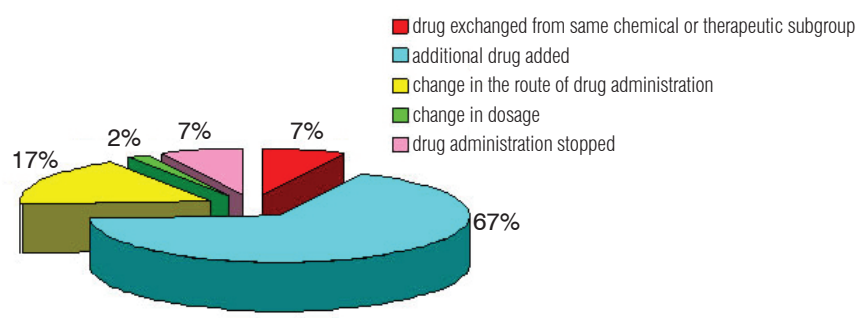

FIGURE 3. Types of change
Predominantly were cases with variations in the therapy performed due to lack of therapeutic effect. Specifying the diagnosis had been reason for change in $26 \%$, administrative problems for $7 \%$ and adverse drug reactions in $4 \%$ only.

\section{CONCLUSIONS}

The study shows that medical doctors do not realize the significance of patient safety problems and its influence on hospital level. We prove the importance of the patient safety incident reporting system on hospital level once again. It can be established as "stand alone" system or can be integrated with other systems for reporting and collecting patient-safety data. The primary objective of an incident reporting system has to be the enhancement of patient safety, by learning from adverse events and mistakes made. Reporting and collection of incident data is meaningful only if the data is analyzed and evaluated. The feedback could be given to all of the professionals and others who are interested and would like to learn more from the events' analysis.

The newest therapeutic considerations in CAP are related to monotherapy versus medicines combinations, parenteral versus oral therapy and/or reliable switch, minimizing the emergence of penicillin-resistant pneumococci and reduction of the hospital stay. Efforts to improve the use of antibiotics for inpatients with CAP should consider the range of barriers that care providers face in everyday practice.

\section{REFERENCES}

1. Wim Schellekens. Patient Safety: The New Challenge. EJHP-P, vol.11 2005/4, www.ejhp.org

2. Carruthers I., Philip P. Safety first - a report for patients, clinicians and healthcare managers. 278137 1p 2.5k Dec 06 (CWP), www.dh.gov.uk/publications

3. Martin J. Recommendation of the Council of Europe to Member States on patient safety. EJHP-P, vol.11 2005/4, www.ejhp.org

4. Nieva V.F., Sorra J. Safety culture assessment: a tool for improving patient safety in healthcare organizations. 
Qual Saf Health Care, 12: 17-23, 2003.

5. Vulto A.G., Surugue J. The hospital pharmacist: your stakeholder for in-hospital medication safety!. EJHP-P, vol.11 2005/4, www.ejhp.org

6. Marlies E J L Hulscher et al. Barriers to optimal antibiotic use for community-acquired pneumonia at hospitals: a qualitative study. Jeroen A Schouten. Qual Saf Health Care, 16: 143-149, 2007. DOI: 10.1136/qshc.2005.017327
7. Bradley A. Sharpe. Guideline-Recommended Antibiotics in Community-Acquired Pneumonia Not Perfect, but Good. Arch Intern Med, 169: 1462-1464, 2009.

8. Ramirez J.A. Managing Antiinfective Therapy of Community-Acquired Pneumonia in the Hospital Setting: Focus on Switch Therapy, 0277-0008, 2001.

9. Clinical Experience with Switch Therapy. Pharmacotherapy, 21: 79-82, 2001. Pharmacotherapy Publications. 